\title{
The Effect of Corporate Governance Mechanisms on Social Responsibility Disclosure
}

\section{Mohammad Hossein Zolfaghar Arani}

\author{
Ph.D. Student in accounting, Faculty of Economics and Business Administration, Ferdowsi University, Mashhad, Iran
} Email:mh_zolfaghararani@stu.um.ac.ir

\author{
Doi:10.5901/mjss.2016.v7n4s2p139
}

\begin{abstract}
The aim of this study was to investigate the relationship between some of the corporate governance mechanisms on social responsibility disclosure. To measure the level of corporate social responsibility information disclosure, according to the research of Nirwanto et al. (2010), a checklist containing 35 types of environmental and social information which were expected to be disclosed voluntary or mandatory in the annual report was developed. The total number of disclosed expressions in any disclosure subgroups represents environmental and social information disclosure level of the company. This paper uses panel data and is tested based on generalized regression method (PGLS model). The data is based on information released by companies listed in Tehran Stock Exchange between 2009 and 2014, and the sample includes 128 companies. The results of this research show a significant relationship between the three mechanisms of corporate governance, including institutional owners, the proportion of non-executive board of directors as well as the size of the board, and the level of social responsibility disclosure. In addition, no significant relationship was found between the auditor size and the level of social responsibility disclosure. Paying attention to social responsibility reporting as a proxy to increase the social role of business units and their growing presence in environmental activities and participation in social and economic development programs, is the most important achievement of this article.
\end{abstract}

Keywords: Social responsibility disclosure, corporate governance, institutional owners, non-executive board of directors.

\section{Introduction}

Corporate social responsibility and its corresponding disclosure is an essential factor that leads to survival of the corporations, because all corporations have some relationships with the society. Therefore, the society ensures the survival of the corporation in the long run. Society takes advantage of the activities of the corporation. The development of the corporate responsibility implies that the responsibilities of corporations has developed beyond what it has been in the past: "providing money for the shareholders". Corporations shall be responsive against beneficiaries (shareholders, customers, staff, product suppliers, banks, lawmakers, environment and the community). Therefore, in addition to economic responsibilities, the corporations shall feel responsibility against social issues. Hence, regarding the importance of the corporates social responsibility and its associated disclosure, enough care shall be taken in financial reports. Supervision and enforcement here requires corporate governance mechanisms. In a study, Hassasyeganeh (2009) argues that corporate governance means laws, regulations, structures, cultures and systems that leads to achievement of goals such as responsiveness, transparency, justice and respecting stakeholders' rights. In a study, Ghaemi and Shahriari (2009), describe corporate governance mechanism as a correlating mechanism of several branch of sciences, such as accounting, economy, financial and rights, by keeping a balance among social and economic goals as well as individual and social goals that leads to persuasion and strengthening the efficient use of resources and responsiveness of the corporates against other beneficiaries.

Corporate governance is a set of internal and external mechanisms that determine how and by whom the corporations are governed, and how a proper responsiveness and information disclosure to beneficiaries should be. Therefore, corporate governance is a process that makes the corporate information transparency disclosed by the managers be of higher quality. The important aspect of corporate governance is the transparency of information, the transparent information can be considered as one of the tools for managers' responsiveness duties. Corporates' social responsibility is considered as a new theme in accounting literature and researches, and is discussed in several aspects investors, analysis, managers and researchers. Today, shareholders are willing to invest at corporations where social responsibilities are performed in an appropriate manner.

In addition, social responsibility discuss ethical matters about the behavior and the decisions made by the corporation about issues such as human resource management, environmental protection, workplace health, social 
relations and relations with suppliers and customers (Castelo and Lima, 2006). Orlitzky et al. (2003) argues that engage in social responsibility activities not only improves shareholder satisfaction, but also have positive effect on the company's reputation. In other words, the disclosure of information about the social responsibility of the corporation have a positive effect on the shareholders of the corporations. The aim of this study was to investigate the relationship of corporate governance mechanisms on corporate social responsibility disclosure of corporations listed on the Stock Exchange of Tehran.

\section{Theoretical Foundations}

\subsection{Corporate Governance}

The word Corporate Governance did not exist in English literature before twenty years ago, however, it has become important in the literature as well as the discussions of the public sector policy makers debates. The subject of corporate governance in its modern from was raised in the early 1990s in England, US and Canada in response to issues related to effectiveness of the board of directors of large companies. Basics and concepts of corporate governance formed with the report provided by Cadbury in England, the regulations of the board of directors at General Motors of America, and later, with development of international capital investment, different institutions such as World Bank. The Organization for Economic Cooperation and Development (OECD), etc., became activated in this regard and published several codes. In recent years, major progress is made on corporate governance in the world and international organizations have provided acceptable standards in this regard. In the last two decades, principles of corporate governance have become one of the fundamental aspects of the business and is increasing in a daily basis.

Based on the findings of researchers such as Black (2001), Klapper and Love (2003), Gompers et al. (2003), corporates' governance principles has an important role in improving the performance of the corporations and there is a direct relationship between the principles of corporate governance and corporation performance in developed under development financial markets. The results of many empirical studies conducted in other countries shows that proper corporate governance leads to the company's good performance. Corporate governance is important for the following reasons:

- It provides a framework for a long time trust among companies and foreign capital provides.

- With appointment of the managers that are founder of new experiences and ideas, strategic thinking is gifted to the top of the corporation.

- Makes the management and supervision on global risk against the corporation logical.

- By sharing decision making process, reliance on senior manager decreases and their responsibility become limited (Ghods, 2009).

\subsection{Corporate social responsibility}

Wave of corporation scandals and financial collapses of large companies and big institutions such as Enron, Arthur Andersen and WorldCom at the beginning of $21^{\text {st }}$ century, represents evidence of unethical and irresponsible commercial procedures in terms of social aspects. In addition, the process of globalization has increased the strength of the corporations and they under increased pressure from the society to have a wider attitude toward social and environmental aspects. The pressure for a more responsible behavior of the commercial units commercial have become a new dilemma for the decision-making process of the corporations compared to common economic saving methods for profit maximization.

Corporate social responsibility is the obligation of the management to actions, protection and improvement of both society welfare in general and the interests of the organizations (Davis, 1975). Social responsibility of the corporation is the obligation of the commercial agency for taking part in sustainable economic development through working with the staff, family, local society local and society in general for improvement of quality of life (Holmes and Wildman, 2001).

The concept of corporations' social responsibility in recent decade has become a dominant and prevailing paradigm in the field of corporate governance, and international large corporations find the responsibility against community and social environment as part of their corporate strategy. The concept is is currently followed seriously by all players including governments, corporations, civil society, international organizations and scientific forums. Corporations find the social responsibility as a kind of commercial strategy that increases their reputation and increase their market share in the highly competitive atmosphere. Social responsibility is a set of duties and commitments that the organization 
shall perform for protection and taking care and help to community where it perform its activities. Social responsibility of the organizations explores the performance of the organization in terms of their impact on the society as well as their impact on the environment, which is considered as an important factor in evaluating the general performance of the organization and its ability to continue its own activities.

Overall, the concept of corporate social responsibility is quite close to the concept of sustainable development that depends on to three key elements of environmental protection, economic growth and social justice and is actually a consequences of sustainable development approach, special attention to the concept of corporate disclosure and social responsibility reporting. The rise and the increase of interest of the corporation toward corporate social responsibility disclosure, reflects the increased demand for transparency that rooted in many factors and response to it involves factors such as: development of corporate social responsibility and its special standards, broader information disclosure in order to meet information requirements of different beneficiaries, providing report on corporate social responsibility performance for investors to reduce their mistrust toward organizations.

\section{Literature Background}

Rahman Khan \& Badrul Mottakin (2013), did a research under the title of "Corporate Governance and Corporate Social Responsibility Disclosures: Evidence from an Emerging Economy" in Bangladesh. In this research the relationship of some of corporate governance including: management ownership, general ownership, foreign ownership, the ratio of nonexecutive managers in the board of directors, dichotomy of CEO and presence of audit committee in one hand and the disclosure of corporate social responsibility was tested. The results showed that the corporate social responsibility disclosure has negative relationship with management ownership. And general and foreign ownership and non-executive managers in board of directors and presence of audit committee has positive and significant effect with corporate social disclosure. Also the results showed that the dichotomy effect of the manager has no significant relationship on social responsibility disclosure.

Arshad \& Razak (2011), in a study with the title "Corporate social responsibility disclosure and interaction effects of ownership structure on firm performance" studied the corporate social responsibility disclosure and the performance of Malaysian corporations. In this research the information of 222 Malaysian corporations between 2006 and 2008 was collected. The results of this study showed that disclosure of social responsibility activities of the corporation has a significant effect able the on success companies has it and the potential oh you lead the performance financial strong and creation value to company an activity of effect on the success of corporations and can potentially lead to a strong financial performance and creating value for the corporations. In addition, the prevailing ownership structure improves social responsibility disclosure activities.

Ho et al. (2011), in a study under the title of "The effect of ownership structure on corporate social responsibility disclosure ", categorized the shareholders according to different motivations, including shareholders with institutional ownership, management ownership and foreign motivations. Data included a sample of 993 Korean corporations.. Results showed that corporate social responsibility has a positive and significant relationship with institutional ownership and foreign ownership. However, the relationship between corporate social responsibility and management ownership is not positive and significant. Studies showed that different groups of shareholders have different impact on social responsibility disclosure.

Oeyono, et al (2011), in study under the title "Corporate social responsibility and financial performance" studied social responsibility and financial performance of 10 Malaysian corporations. In this research, gross interest and depreciation and profit per share was considered as financial performance variables. The research took place between 2003 and 2007. Their analysis showed that there is a positive and rather weak relationship between corporate social responsibility and financial performance. Hence they argued that corporate social activity reporting improves financial performance.

Werner (2009) in a study under the title Corporate Social Responsibility, an Introduction to Social Restrictions in Bangladesh, concluded that corporate social responsibility has potential, positive and stable effect in under development countries, specially societies with social restrictions.

Zabihimanesh (2012), studied the relationship between intellectual capital and its components including capital efficiency (human capital efficiency and structural capital), and corporate social responsibility disclosure. The results showed that intellectual capital has no significant relationship with corporate social responsibility. However, one of its components, i.e., capital efficiency, has a significant impact on corporate social responsibility disclosure. While the two other components of intellectual capital, i.e., human capital efficiency and structural capital had no significant effect on corporate social responsibility disclosure. In addition, the results of the research could prove that corporate social 
responsibility understanding is not yet in a level to enable corporations fulfill corporate social responsibility voluntarily.

Mousavi and et al. (2010), studied the effect of corporate governance mechanisms (ownership concentration) on corporate performance (assets return rate, shareholders rights return rate, and the market value to book value ratio) and showed that there is a significant relationship between ownership concentration and assets return rate, however, there was no relationship between ownership concentration and shareholders rights return rate, and the market value to book value ratio.

Mortazavi et al. (2010), studied the role of moderating social responsibility importance variable on the relationship among four social responsibility aspects (staff, customers, government and social and non-social beneficiaries) in food industry food companies in Mashhad, Iran. Accordingly, food industry was considered as the case study and the statistical sample included 901 member and the information was collected using questionnaire.

Processing the data using hierarchy regression model indicates that the moderator role of variable under study on the relationship among four dimension of social responsibility (employees, customers, government and social and nonsocial beneficiaries) is confirmed. This finding means that the emphasis on importance of social responsibility and its observance by thr organizations can have a positive functional effect on organizations, so that it affect organizational responsibility of the staff in a significant way.

Foroughi et al. (2007), in a research studied the attitude of managers of manufacturing corporations accepted in Tehran Stock Exchange toward social accounting information disclosure, based on the political economy, legitimation and beneficiary groups theories. The results of the study is in line with the above theories and shows that executives of Iranian corporations are willing to disclosure information related to social interests and issues related to the welfare of their staff, but are not willing to disclosure information related to social costs.

\section{Research Hypotheses}

First hypothesis: There is a significant relationship between institutional ownership and the level of corporate social responsibility disclosure.

Second hypothesis: There is a significant relationship between the proportion of non-executive managers in the board of directors and the level of corporate social responsibility disclosure.

Third hypothesis: There is a significant relationship between board size and the level of corporate social responsibility disclosure.

Fourth hypothesis: There is a significant relationship between auditor size and the level of corporate social responsibility disclosure.

\section{Methodology}

In terms of purpose, this is an applied research, and in terms of nature, this is a descriptive study with an emphasis on correlation relationships, and it falls within the scope of ex-post facto researches, because it is based on real information from financial statements of corporations listed on the Tehran Stock Exchange, which can be generalized to the entire statistics population by the inductive method. For collecting the information of sample corporations, electronic archives and resources such as Rahavard Noving software and Tehran Stock Exchange Codal website are used. Then the extracted raw data were entered into Excel spreadsheet were prepared for the analysis and finally, the derived variables were imported into EViews7 statistical software and in some cases R Software to check for any correlation.

The statistical population of this research are the corporations listed in the Tehran Stock Exchange between 2009 and 2014, and the sample was selected based on following criteria:

- Their financial year have to be ended in 19 March each year.

- Have not changed their fiscal year during the research period.

- Their financial statements were continuously and completely available from 2009.

- For homogeneity, they are not among investment and financial intermediation (banks and leasing) types of corporations.

Based on the above criteria, 128 corporations were selected between 2009 and 2014.

\subsection{Hypothesis test model}

In this study, for identifying the relationship between corporate governance mechanisms and corporate social 
responsibility disclosure, the study conducted by Badrul Muttakin et al. (2015) is used:

$C_{S R D_{i t}}=\beta_{0}+\beta_{1}$ OWNCON $_{i t}+\beta_{2}$ OUTDIR $_{i t}+\beta_{3}$ BSIZE $_{i t}+\beta_{4}$ AUDSIZE $_{i t}$

$+\beta_{5} S_{Z Z E}+\beta_{6} A G E_{i t}+\beta_{7} R O A_{i t}+\beta_{8} L E V_{i t}+\varepsilon_{i t}$

Where in the above model, the variables are defined as follows:

CSRD : Is the total measures of corporates' social responsibility, and to measure it, content analysis method is used. Content analysis is a text coding method into different groups according to predefined measures, which is widely used in the researches related to environmental and social information disclosure, because the metod provides a systematic approach for analyzing large non-structural data. In content analysis, the researcher has to employ a coding checklist for evaluating environmental and social information disclosure level (Nirwanto et al., 2011).

In the present study, in order to measure corporate environmental and social information disclosure level, an initial checklist including 43 types of information was prepared after intensive review of related literature, and the information was acquired from Nirwanto et al (2001) and Jao, Heravi and Sialo (2005) researches. After elimination of some items, the final checklist including 35 kind of environmental and social information was prepared, which is expected to be voluntary or mandatory disclosed in the corporations' annual report. After preparing the checklist, coding rules were determined, and each disclosure subgroups was defined clearly and operationally, so that it could be exactly specified that each term belongs to what group and subgroup. The total number of disclosed terms in each subgroups of each group represents the company's environmental and social disclosure level.

OWNCON: Institutional ownership variable, the ratio of common stock owned by active institutional owners (institutional owners having a representative in the board).

OUTDIR: The ratio of non-executive board of directors is the number of non-executive directors to the total number of members of the Board of Directors.

BSIZE: The size of the board. It is the natural logarithm of the number of members of the Board of Directors.

AUDSIZE The size of the auditor. In an organizations where auditing is done by Audit Department the dummy variable is equal to one, otherwise is zero.

SIZE: Is equal to natural logarithm of the total assets of the company.

AGE : Natural logarithm of the company's life.

LEV The ratio of the book value of debts to book value of assets.

ROA The ratio of net profit to total assets.

\section{Research Findings and Empirical Results}

\subsection{Descriptive statistics 6.1.}

In order to initial analysis of the data, descriptive statistics of variables under study are calculated and are presented in Figure (1). This table contains information about the mean, median, minimum, maximum, and standard deviation.

Figure (1): Descriptive statistics of research variables

\begin{tabular}{ccccccc}
\hline Variable & Number of Views & Average & Middle & Standard deviation & Lowest & The maximum amount \\
\hline CSRD & 768 & 9.807 & 9.000 & 4.222 & 1 & 25.000 \\
OWNCON & 768 & .567 & 0.690 & 0.316 & 0.000 & 0.990 \\
OUTDIR & 768 & 0.652 & 0.600 & 0.156 & 0.200 & 0.800 \\
BSIZE & 768 & 1.611 & 1.609 & 0.041 & 1.609 & 1.945 \\
SIZE & 768 & 12.933 & 12.830 & 1.575 & 8.216 & 18.521 \\
AGE & 768 & 2.701 & 2.708 & 0.408 & 3.850 & 1.609 \\
LEV & 768 & 0.627 & 0.598 & 0.412 & 0.241 & 0.872 \\
ROA & 768 & 0.236 & 0.182 & 0.892 & 1.227 & -0.379 \\
\hline
\end{tabular}

The number of samples included 128 corporations in a period of 6 years between 2009 and 2014, with a total of 768 observation (year - corporation). As it can be seen in the above figure, the average of the variable related to the total number of corporate social responsibility of the samples shows 10 (to be precise 9.807), which indicates that from a total of 35 types of environmental information disclosed by companies which listed in the checklist of the study, Stock Exchange corporations disclose something about 28 percent of it, and this is in line with what is expressed in the theoretical basis of this study, ie., unwillingness of corporations about disclosing information on social responsibility. 


\section{Research Hypotheses Test}

In using panel date, different models are used to test the hypotheses. These include methods such as fixed effects, random effects model and pooled data models. In order to test the hypothesis, first Eviews application was used to examine the test model, test F Limer (Chow), Hausman test and continuous integration test have been used (Baksh Shamsollah and Khansari, 2005). The results of the F Limer test (Chow) for the model are as follows:

Figure (2): Research model F Limer test results

\begin{tabular}{lcc}
\hline Test & Test Statistic & Test probability \\
\hline F Limer Test & 13.485 & 0.000 \\
\hline
\end{tabular}

The significance level is less than 0.05 , as a result, using panel data is accepted. Given that the panel data approach was adopted, Hausman test is used to select between fixed and random effects methods.

PD Tuesday The results of the research model Hausman test

\begin{tabular}{lcc}
\hline Test & Test statistic & Test probability \\
\hline Hausman test & 7.736 & 0.257 \\
\hline
\end{tabular}

To study the results of Hausman test, if the test statistical probability is more than 0.05 , random effects method should be used. Otherwise, the fixed effects model is used. Figure (3) suggests that the possibility of the test is more than 0.05 , as a result the random effects model will be accepted. The final step for determining the appropriate fitness method for the model is to check the possibility of integration of time, place or both of these factors. To prove this, we used Lagrange multiplier test (LM) in Pagan method, the results of which are summarized in Figure (4):

Figure (4): Test results of time and space integration possibility

\begin{tabular}{lccl}
\hline The null hypothesis $\left(\mathrm{H}_{0}\right)$ & Chi -square Statistic & $\mathrm{P}$-Value & Test result \\
\hline Time integration is possible & 1.813 & 0.178 & $\mathrm{H}_{0}$ not rejected: Time Integration possible. \\
Space integration is possible & 20.841 & 0.000 & $\mathrm{H}_{0}$ rejected: Space Integration not possible. \\
Time and space integration is & 9.664 & 0.000 & $\begin{array}{l}\mathrm{H}_{0} \text { rejected: Time and space Integration not } \\
\text { possible. }\end{array}$ \\
possible time & & 0.00
\end{tabular}

According to Chi - square test values resulted from Lagrange multipliers test in Pagan method according to the above table, it can be concluded that the time factor integration method of is suitable for the model. Now that the method for the model were determined, the default hypotheses of regression models have to be tested. In practice, control and fulfillment of all the default assumptions are neither conventional nor is practical, and even some experts do not find these control and fulfillment of all the default assumptions necessary (Sarmad et al., 2008). But the most important condition for using the integration panel model, is the lack of auto-correlation between the error terms. To check this condition, BreuschGodfrey test was used in this study. The results of this test on details of the model resulted from R software is as follows:

Figure (5): Breusch-Godfrey test results (no auto-correlation)

\begin{tabular}{lccl}
\hline Hypothesis $\mathrm{H}_{0}$ & Chi -square Statistic & $\mathrm{P}$ - Value & Test result \\
\hline $\begin{array}{l}\text { The lack of correlation } \\
\text { between the error terms }\end{array}$ & 392.296 & $0.001>$ & $\begin{array}{l}\text { Hypothesis } \mathrm{H}_{0} \text { rejected: Correlation between } \\
\text { the error terms }\end{array}$ \\
\hline
\end{tabular}

Given that the P - Value in Breusch-Godfrey test is less than 0.001 , therefore the null hypothesis that there is no serial auto-correlation between model disturbing components is rejected, and therefore error have serial auto-correlation. The existing of auto-correlation between the model residuals will cause a bias in model estimation. To solve this problem and to better estimate the model parameters, generalized panel model (PGLS) method is used for final model fitting. Figure (6) shows the results of a final estimation of the model: 
Figure (6): Final fitness results of the model

\begin{tabular}{|c|c|c|c|c|c|}
\hline Variable name & $\begin{array}{l}\text { Variable } \\
\text { symbol }\end{array}$ & $\begin{array}{c}\text { The regression } \\
\text { coefficient }\end{array}$ & $\begin{array}{l}\text { Standard } \\
\text { deviation }\end{array}$ & $\begin{array}{c}\text { Test } \\
\text { Statistic }\end{array}$ & $\begin{array}{c}\mathrm{P}- \\
\text { Value }\end{array}$ \\
\hline Constant value & Intercept & 0.163 & 0.138 & 1.163 & 0.245 \\
\hline Institutional ownership & OWNCON & 0.531 & 0.102 & 5.175 & $\begin{array}{c}0.001> \\
\star \star \star\end{array}$ \\
\hline $\begin{array}{l}\text { The ratio of non-executive } \\
\text { directors }\end{array}$ & OUTDIR & 0.475 & 0.135 & 3.522 & $\underset{* \star}{0.0004}$ \\
\hline $\begin{array}{l}\text { Board size } \\
\text { Auditor size }\end{array}$ & $\begin{array}{c}\text { BSIZE } \\
\text { AUDSIZE }\end{array}$ & $\begin{array}{l}0.107 \\
-0.471\end{array}$ & $\begin{array}{l}0.045 \\
0.310\end{array}$ & $\begin{array}{r}2.389 \\
-1.518\end{array}$ & $\begin{array}{c}0.017^{*} \\
0.129\end{array}$ \\
\hline size of the company & SIZE & -0.263 & 0.040 & -6.435 & $\underset{* \star *}{0.001>}$ \\
\hline $\begin{array}{l}\text { Company life } \\
\text { Financial Leverage } \\
\text { Return of Assets }\end{array}$ & $\begin{array}{l}\text { AGE } \\
L E V \\
R O A\end{array}$ & $\begin{array}{l}0.276 \\
0.230 \\
0.049\end{array}$ & $\begin{array}{l}0.213 \\
0.106 \\
0.052\end{array}$ & $\begin{array}{l}1.303 \\
2.164 \\
0.955\end{array}$ & $\begin{array}{c}0.192 \\
0.030 \text { * } \\
0.340\end{array}$ \\
\hline \multicolumn{6}{|c|}{ The significance level (a error level): 0.001 for " * * * ", 0.01 for the "* * " , 0.05 for "*" } \\
\hline $\begin{array}{l}\text { Coefficient of Determination }\left(\mathrm{R}^{2}\right) \\
\text { Adjusted coefficient of } \\
\text { determination }\left(\mathrm{Adj} . \mathrm{R}^{2}\right)\end{array}$ & $\begin{array}{l}0.418 \\
0.409\end{array}$ & \multicolumn{2}{|c|}{$P-F$ statistics } & \multicolumn{2}{|c|}{0.000} \\
\hline
\end{tabular}

According to the above table, and the value of $\mathrm{F}$ statistic of the model which is equal to 8.394 ( $\mathrm{F}$ statistics probability equal to 0.000 ), it can be concluded that the model is designed rather properly, and variable coefficients are valid at the aggregate level. The coefficient of determination of the model shows that about 41 percent of dependent variable changes are explained by the explanatory variables.

The first hypothesis of this study showed a significant relationship between institutional ownership and social responsibility disclosure level. According to the statistics calculated for this variable in the model and its significance level that indicates a number less than 0.001 , it can be inferred that this hypothesis will be accepted. In addition, considering the coefficient of this variable which is equal to 0.531 , we can conclude that there is a direct and significant relationship between institutional owners and social responsibility disclosure level. This has similarly been proven already in a research by Oeyono et al. (2011) as well as Badrul Muttakin et al (2015).

The relationship between the proportion of non-executive directors and corporate social responsibility disclosure level, is expressed in the second hypothesis. With regards to the value of test statistical probability associated with this variable that is 0.0004 , one can argue that in the sample of the current study, this hypothesis is proven.

The regression coefficient of this variable is equal to 0.475 , which shows the above relationship is positive. Similarly, this result is proven in the study concluded by Foroughi et al. (2007) and Badrulmotakin et al. (2015), and is in contrast to the results of the study conducted by Werner (2009). The third hypothesis of this study deals with the relationship between the size of the board of directors and corporate social responsibility disclosure level. With regard to the $\mathrm{P}$ - value of this variable in the model which is 0.017 , it can be concluded that this hypothesis is also accepted, while according to the regression coefficient calculated for this variable which is 0.107 , the relationship is a direct and significant one. Similarly the above result is presented in the research of Badrulmotakin et al. (2015) and Hu et al. (2011).

The fourth hypothesis of this study refers to the relationship between auditor size and level of social responsibility disclosure. The probability of the test statistic of this variable in this model is 0.129 , which indicates the rejection of this hypothesis. This result contrasts with the findings of the study by Badrulmottaking et al. (2015) , Werner (2009) and Hu et al. (2011).

\section{Research Suggestions}

Based on the results obtained during the investigation, the following suggestions are offered:

$\checkmark$ Given the role of corporate governance in reporting social responsibility in corporation mentioned earlier in this study, the shareholders and non-executive directors are suggested to give priority to corporate social responsibility disclosure when planning for corporate governance principal implementation.

$\checkmark$ Due to the fact that social responsibility reporting increases social role of business and increases their presence in both environmental activities and their contribution in economic and social development activities, we propose to the corporations' managers to give priority to social responsibility reporting. 


\section{References}

Arab Salehi, Mehdi. Ziaee Mohammad Ali (2010) "Relationship between governance system and quality of earnings in corporations accepted by Tehran Stock Exchange" Financial Accounting Academic Quarterly, Year 2 , No 5, P. 39-56.

Arshad, R., \& Razak, S. N. A. A. (2011). "Corporate social responsibility disclosure and interaction effects of ownership structure on firm performance". In Business, Engineering and Industrial Applications (ISBEIA), 2011 IEEE Symposium on (pp. 111-116). IEEE.

Badrul Muttakin, M., Khan, A., Subramaniam, N. (2015). "Firm characteristics, board diversity and corporate social responsibility Evidence from Bangladesh", Paciic Accounting Review, Vol. 27 No. 3, pp. 353-372.

Baker, M., \& Gompers, P. A. (2003). "The Determinants of Board Structure at the Initial Public Offering". Journal of Law and Economics, 46(2), 569-598.

Black, B. (2001). "The corporate governance behavior and market value of Russian firms". Emerging Markets Review, 2(2), 89-108.

Castelo Branco, M., \& Lima Rodrigues, L. (2006). "Communication of corporate social responsibility by Portuguese banks: A legitimacy theory perspective". Corporate Communications: An International Journal, 11(3), 232-248.

Deakin, S., Hobbs, R., Konzelmann, S. J., \& Wilkinson, F. (2004). "Working corporations". Partnership and Modernisation in Employment Relations, 55.

Foroughi, Dariush. Mir Shams Shahshahani, Morteza, Pourhossein Somayyeh (2007) "Attitude of managers about Social Accounting Information disclosure in corporations accepted by Tehran Stock Exchange" Accounting And Auditing Reviwes Quarterly, Year 15, No. 52.

Geva, A. (2008). "Three models of corporate social responsibility: Interrelationships between theory, research, and practice". Business and Society Review, 113(1), 1-41.

Ghaemi, Mohammad Hossein and Mehdi Shahriari (2009) "Corporate governance and financial performance of corporations", Accounting progresses, first period, number 1, serial 57.3, , pp. 113-128 .

Gompers, P. A., Ishii, J. L., \& Metrick, A. (2001). Corporate governance and equity prices (No. w8449). National bureau of economic research.

Hashemi, Seyed Abbas. Bakrany, Keyvan (2010); "The impact of Ownership Structure And Corporate governance System On Capital Structure decisions in the corporations Accepted By Tehran stock Exchange", Financial Accounting Academic Quarterly, Year 9 , No 3 , P. 144-155.

Hassasyeganeh, Yahya. (2006). "Corporate governance in Iran ". Auditor Quarterly, №. 32.

Khan, A., Muttakin, M. B., \& Siddiqui, J. (2013). "Corporate governance and corporate social responsibility disclosures: Evidence from an emerging economy". Journal of business ethics, 114(2), 207-223.

Klapper, L. F., \& Love, I. (2004). "Corporate governance, investor protection, and performance in emerging markets". Journal of corporate Finance, 10(5), 703-728.

Minnick, K., \& Noga, T. (2010). "Do corporate governance characteristics influence tax management?" Journal of Corporate Finance, 16(5), 703-718.

Mortazavi, Saeed., Poorazad, Naser, Amir Razavi Pegah, Sadeghi Moghaddam, Masoumeh (2010) " Moderating role of social responsibility importance variable on the relationship between quadriple dimensions of social responsibility and organizational commitment" Social Sciences Journal, College of Literature and Human Sciences, Ferdowsi University of Mashhad, year 1, pp. 291-318.

Mousavi, Zahra. Moridipur, Hamid. Jari Azam, (2010) "Assessment the impact corporate governance regulatory mechanisms on activities of corporations accepted by Tehran Stock Exchange" Operation Listed companies By At Market PapersTehran stock ", Financial Accounting Academic Quarterly, Year 2, No 2, P. 141-155.

Muttakin, M. B., Khan, A., \& Subramaniam, N. (2015). "Firm characteristics, board diversity and corporate social responsibility: Evidence from Bangladesh". Pacific Accounting Review, 27(3), 353-372.

Nirwanto, Mirza.Zulaikha. Rahardja, H.(2011),"Corporate social responsibility disclosure and its relation on institutional ownership: Evidence from public listed companies in Malaysia 2008-2010" , Managerial Auditing Journal.

Oeyono, J., Samy, M., \& Bampton, R. (2011). "An examination of corporate social responsibility and financial performance: A study of the top 50 Indonesian listed corporations". Journal of Global Responsibility, 2(1), 100-112.

Oh, W. Y., Chang, Y. K., \& Martynov, A. (2011). "The effect of ownership structure on corporate social responsibility: Empirical evidence from Korea". Journal of business ethics, 104(2), 283-297.

Orlitzky, M., Schmidt, F. L., \& Rynes, S. L. (2003). "Corporate social and financial performance: A meta-analysis". Organization studies, 24(3), 403-441.

Prior, D., Surroca, J., \& Tribó, J. A. (2008). "Are socially responsible managers really ethical? Exploring the relationship between earnings management and corporate social responsibility". Corporate Governance: An International Review, 16(3), 160-177.

Scholtens, B., \& Kang, F. C. (2013). "Corporate social responsibility and earnings management: Evidence from Asian economies". Corporate Social Responsibility and Environmental Management, 20(2), 95-112.

Sherbet Oghli, Ahmed. Afshari, Davoud and Najmi, Manouchehr. (2010) "Measuring social responsibility in corporations accepted by Tehran Stock Exchange" Iran's Management Science Quarterly, No 93, pp. 29-41.

Werner, W. J. (2009). "Corporate social responsibility initiatives addressing social exclusion in Bangladesh". Journal of health, population, and nutrition, 27(4), 545. 